ISSN Print : 1411 - 951 X, ISSN Online : 20503-1716

Jurnal Ergonomi Indonesia

(The Indonesian Journal of Ergonomic)

Vol.3, No.1 : 1 Januari-Juni 2017

\title{
PENAMBAHAN ALAS MESIN DAN PEMBERIAN PEREGANGAN DINAMIS DI BAGIAN PROSES PEMOTONGAN SINGKONG MENURUNKAN BEBAN KERJA, KELUHAN MUSKULOSKELETAL, DAN MENINGKATKAN PRODUKTIVITAS KERJA PADA INDUSTRI KERIPIK SINGKONG
}

\author{
${ }^{1}$ Meiza Anniza, ${ }^{2}$ Ketut Tirtayasa, ${ }^{3}$ I Made Muliarta
}

1. Mahasiswa Program Studi Magister Ergonomi Fisiologi Kerja Universitas Udayana

2. Staff Dosen Program Studi Magister Ergonomi Fisiologi Universitas Udayana

3. Staff Dosen Program Studi Magister Ergonomi Fisiologi Universitas Udayana

meizaannisa@yahoo.com

\begin{abstract}
ABSTRAK
Mesin pemotong singkong merupakan alat memotong singkong dengan ketebalan \pm 1 s.d $2 \mathrm{~mm}$. Tinggi landasan kerja mesin pemotong singkong berada di bawah tinggi siku berdiri pekerja. Sehingga pada saat bekerja, pekerja mengambil singkong untuk dimasukkan ke dalam mesin dengan cara membungkuk dan meletakkan singkong ke mesin pemotong satu persatu sampai singkong terpotong. Intervensi ergonomi yang dilakukan adalah dengan membuat tambahan alas pada mesin pemotong singkong. Penelitian ini bertujuan untuk membuktikan pengaruh penambahan alas mesin dan pemberian peregangan dinamis di bagian proses pemotongan singkong menurunkan beban kerja, keluhan muskuloskeletal, dan meningkatkan produktivitas kerja pada industri keripik singkong.

Penelitian menggunakan rancangan sama subjek (treatment by subjects design) dengan jumlah sampel 9 pekerja. Beban kerja dengan cara mengukur denyut nadi pekerja. Keluhan muskuloskeletal di ukur dengan kuesioner nordic body map, dan produktivitas di ukur dengan perbandingan antara hasil produksi pemotongan singkong dibagi beban kerja dikalikan waktu kerja. Data dianalisis dengan uji $\mathrm{t}$ - paired dengan taraf signifikan $\mathrm{p}<0,05$.

Hasil analisis menunjukkan setelah di tambahkan alas mesin terjadi perbedaan yang bermakna $(\mathrm{p}<0,05)$ antara Periode 1 dan Periode 2 yaitu: (1) penurunan beban kerja pekerja dari 102,41 denyut permenit menjadi 95,51 denyut permenit, (2) penurunan keluhan muskuloskeletal dari rerata skor 33,56 menjadi 31,56, dan (3) peningkatan produktivitas kerja dari 1,64 menjadi 3,58.

Disimpulkan bahwa penambahan alas mesin dan pemberian peregangan dinamis di bagian proses pemotongan singkong menurunkan beban kerja, keluhan muskuloskeletal, dan meningkatkan produktivitas kerja pada industri keripik singkong. Disarankan untuk menurunkan beban kerja, keluhan muskuloskeletal, serta meningkatkan produktivitas kerja pada pekerja pemotong singkong maka disarankan untuk memberikan penambahan alas mesin dan melakukan gerakan peregangan dinamis.
\end{abstract}

Kata Kunci : Alas Mesin, Peregangan Dinamis, Beban Kerja, Keluhan Muskuloskeletal, Produktivitas 
ISSN Print : 1411 - 951 X, ISSN Online : 20503-1716

Jurnal Ergonomi Indonesia

(The Indonesian Journal of Ergonomic)

Vol.3, No.1 : 1 Januari-Juni 2017

\section{THE ADDITION OF BASE SUPPORT AND THE PROVISION OF DYNAMIC STRETCHING IN THE PROCESS OF CUTTING CASSAVA REDUCE WORKLOAD, MUSCULOSKELETAL DISORDERS, AND INCREASING WORK PRODUCTIVITY AT CASSAVA CHIPS INDUSTRY \\ ABSTRACT}

Cassava cutting machine is a tool to cut the cassava into thin sheets with a thickness of 1 to $2 \mathrm{~mm}$. High base of work cassava cutting machine is under worker's elbow height. So during the work, the workers took the cassava to put into the machine by means of bending and putting cassava to cutting machine one by one until the cassava is cut off. Ergonomics intervention is making an additional pad on cassava cutting machine. The purpose of this research was to prove the effect of adding pad machines and the provision of dynamic stretching at the cutting process of cassava reduce the workload, musculoskeletal disorders, and increasing work productivity at cassava chips industry.

Research was conducted by the same design subject (treatment by subjects design) with a sample of nine workers. Workload by measured the pulse of the workers. Musculoskeletal disorders measured by nordic body map questionnaire, and productivity is measured by a comparison between the results of cuts cassava production is divided workload multiplied working time. Data analyzed by $\mathrm{t}$ - paired with a significant level of $\mathrm{p}<0.005$.

The analysis showed after adding pad machine occurs a significant difference $(\mathrm{p}<0.05)$ between before and after treatment: (1) decreases in workload of workers from 102.41 beats per minute become 95.51 beats per minute, (2) decrease musculoskeletal disorders from the average score of 33.56 into 31.56, and (3) increase work productivity from 1.64 to 3.58 .

It was concluded that the addition of base support and the provision of dynamic stretching at the process of cutting cassava reduce the workload, musculoskeletal disorders, and increasing work productivity in cassava chips industry. It is suggested in the effort to reduce the workload, musculoskeletal disorders, as well as increasing work productivity in cassava cutting workers so it is suggested to addition of base support and do dynamic stretching movements.

\section{Keywords: Base Support, Dynamic stretching, Workload, Musculoskeletal disorders, Productivity}

\section{PENDAHULUAN}

Industri keripik singkong merupakan usaha padat karya yang dapat meningkatkan pendapatan. Selain untuk dikonsumsi di kalangan sendiri, pengelola ingin mendapatkan keuntungan yang setinggi-tingginya, sementara itu tidak di perhatikan kondisi sumber daya manusianya.

Di industri keripik singkong, proses kerja yang dilakukan sebenarnya cukup sederhana yaitu dimulai dari proses pengupasan singkong, pencucian, pemotongan, penggorengan, dan pengemasan keripik. Pada survei pendahuluan, di bagian proses pemotongan singkong pekerja menggunakan mesin pemotong singkong yang berfungsi sebagai pemotong singkong dalam jumlah yang banyak dan secara kontinyu.

Proses operasional mesin dengan memasukkan singkong pada mata pisau yang dipasang pada piringan berputar. Sebelum digunakan, mesin pemotong dan baki untuk menyimpan hasil pemotongan diletakkan di lantai, dengan panjang mesin 


\section{Jurnal Ergonomi Indonesia}

\section{(The Indonesian Journal of Ergonomic)}

$50 \mathrm{~cm}$, lebar $45 \mathrm{~cm}$, dan tinggi mesin 70 $\mathrm{cm}$. Hal ini perlu di perhatikan saat melakukan pekerjaan dengan sikap berdiri adalah ketinggian landasan kerja terhadap siku berdiri yang harus di sesuaikan dengan jenis pekerjaannya. Sehingga pada saat bekerja, pekerja mengambil singkong untuk dimasukkan ke dalam mesin dengan cara membungkuk dan meletakkan singkong ke mesin pemotong satu persatu sampai singkong terpotong. Untuk mempebaiki stasiun kerja dengan memberikan tambahan meja sebagai alas pemotong singkong.

Menurut Grandjean (2000) pekerjaan yang memerlukan tekanan, tinggi landasan kerjanya sekitar $10-15 \mathrm{~cm}$ di bawah tinggi siku berdiri. Dalam hal ini perlu penambahan alas kerja dengan tinggi siku berdiri para pekerja yang disesuaikan dengan ukuran antropometri pekerja. Antropometri merupakan ukuran - ukuran tubuh manusia secara alamiah baik dalam melakukan aktivitas statis maupun dinamis (Sutalaksana dalam Sanjaya, 2013).

Rerata denyut nadi kerja pekerja pemotong singkong adalah 120 denyut/menit, yang tergolong beban kerja sedang (Sanders and Mc Cormick, 1987). Beban kerja yang dirasakan berat terjadi pada saat mengambil dan meletakkan singkong ke dalam mesin pemotong, karena tinggi mesin pemotong yang berada lebih rendah dari tinggi siku pekerja pada saat berdiri, sehingga pekerja lebih banyak melakukan gerakan membungkuk. Pekerja cepat merasa lelah dan sering mengeluh sakit pada bagian punggung, pinggang, dan lutut. Untuk mengatasi hal ini pekerja sering istirahat dengan duduk di dingklik. Akibat beban kerja tersebut pekerja cepat lelah, baik secara fisik maupun psikologis sehingga pekerja sering melakukan

\section{Vol.3, No.1 : 1 Januari-Juni 2017}

istirahat curian yang mengakibatkan jam kerja berkurang yang pada akhirnya produktivitas kerja menjadi turun.

International Labour Office (ILO) yang bekerjasama dengan International Ergonomics Association (IEA), merekomendasikan bahwa untuk pekerjaan yang berulang-ulang sebaiknya digunakan peralatan khusus yang disesuaikan dengan kebutuhan operasi, penggunaannya aman, dan harganya murah sehingga bisa mempercepat operasi, dan dapat meningkatkan produktivitas. Berbagai faktor yang harus diperhatikan pada alat bantu kerja adalah seperti ukuran, dimensi, cara kerja, sikap kerja, agar sesuai dengan kemampuan, kebolehan, dan batasan pekerja (Manuaba, 1992a; Suma'mur, 1995; Grandjean, 1998).

Berdasarkan hasil kuesioner identifikasi hazard melalui checklist ergonomic assessment yang diberikan pada saat studi pendahuluan, pekerjaan yang dilakukan pemotong singkong dapat di golongkan bersifat sikap statis terus menerus. Pekerja menyatakan bahwa pada saat memotong singkong terjadi gerakan statis selama aktivitas berkepanjangan, serta stasiun kerja yang kurang mendukung terhadap berlangsungnya proses bekerja.

Upaya pencegahan untuk mengurangi tingkat keluhan nyeri punggung bawah pada pekerja dalam melakukan pekerjaan dapat dilakukan melalui aplikasi ergonomi yang salah satunya adalah dengan pemberian latihan peregangan otot. Diperlukan kesiapan dari tubuh pekerja ketika akan memulai pekerjaan sehingga diharapkan dapat memperkecil atau bahkan menghilangkan keluhan musculoskeletal (Daryono, dkk, 2016). 


\section{Jurnal Ergonomi Indonesia}

\section{(The Indonesian Journal of Ergonomic)}

Salah satu bentuk persiapan tubuh sebelum bekerja adalah dengan melakukan peregangan. Peregangan dapat dilakukan di sela pekerjaan untuk mengurangi ketegangan otot, memperbaiki peredaran darah, mengurangi kecemasan, perasaan tertekan, kelelahan, membuat pekerja merasa lebih baik (Anderson, 2010).

Sikap kerja membungkuk dalam keadaan statis dapat menimbulkan kondisi patologis pada sistem muskuloskeletal, seperti timbulnya keluhan low back pain. Sehingga penambahan alas mesin yang dikombinasi dengan pemberian latihan tertentu dapat dilakukan sebagai upaya pencegahan. Salah satu bentuk latihan yang dapat diberikan adalah peregangan dinamis. Pemberian peregangan dinamis dapat mengembalikan elastisitas sarkomer. Peregangan dinamis dapat mencegah dan mengurangi kekakuan dan perasaan yang tidak nyaman. Peregangan dinamis dapat berpengaruh terhadap semua otot, seperti otot Erector spine dan otot Hamstring yang membatasi gerakan sehingga mendapatkan hasil terjadinya peningkatan fleksibilitas (Samson, et al., 2012). Fleksibilitas yang dimaksud adalah kemampuan menggerakkan sendi tanpa adanya hambatan gerak serta bebas nyeri yang tergantung pada ekstensibilitas sendi yang bersangkutan.

\section{MATERI DAN METODE}

\section{Rancangan Penelitian}

Penelitian ini merupakan penelitian eksperimental, dengan menggunakan rancangan sama subjek (treatment by subject design). Rancangan ini, selang antara periode waktu diperlukan washing out, untuk menghilangkan efek periode pertama terhadap periode berikutnya.

\section{Vol.3, No.1 : 1 Januari-Juni 2017}

Penelitian ini bertujuan untuk membuktikan pengaruh penambahan alas mesin dan pemberian peregangan dinamis di bagian proses pemotongan singkong menurunkan beban kerja, keluhan muskuloskeletal, dan meningkatkan produktivitas kerja pada industri keripik singkong.

\section{Populasi dan Sampel}

Populasi target dalam penelitian ini merupakan seluruh pemotong singkong di Desa Cicadas, dan populasi terjangkau adalah seluruh pemotong singkong yang ada di Industri Keripik Singkong Kharisma.

Teknik

$$
\text { penentuan }
$$

sampel menggunakan random sampling sederhana. Dari jumlah populasi yang ada, dipilih sampel sesuai dengan kriteria inklusi. Jumlah sampel yang dibutuhkan adalah 9 orang. Umur subjek penelitian adalah berkisar antara 28-45 tahun dengan pengalaman kerja 1-5 tahun.

\section{Instrumen Penelitian}

Beban kerja merupakan beban yang diterima oleh pekerja baik dari dalam maupun dari luar tubuh pekerja selama melakukan pekerjaannya yang dihitung berdasarkan rerata peningkatan denyut nadi.

Keluhan muskuloskeletal pada subjek diukur dengan menggunakan kuesioner Nordic Body Map. Pengukuran tersebut bersifat subjektif. Sebelum dan sesudah memulai pekerjaan pada masing-masing periode, seluruh subjek mengisi kuesioner Nordic Body Map.

Produktivitas kerja dihitung berdasarkan rumus sebagai berikut:

\begin{tabular}{|lc|} 
Produktivitas $=$ & Luaran (Output) \\
(time) & Masukan (input) x Waktu \\
\hline
\end{tabular}


ISSN Print : $1411-951 \mathrm{X}$, ISSN Online : 20503-1716

Jurnal Ergonomi Indonesia

(The Indonesian Journal of Ergonomic)

Vol.3, No.1 : 1 Januari-Juni 2017

Indikator produktivitas kerja, adalah:

1. Luaran (Output) adalah rerata jumlah singkong yang dipotong per satuan waktu untuk masing-masing kelompok pekerja pemotong singkong.

2. Masukan (Input) adalah tenaga yang dikeluarkan selama melakukan pekerjaan memotong singkong dengan menggunakan alas mesin yang didasarkan pada rerata nadi kerja kelompok pekerja pemotong singkong (denyut/menit).

3. Waktu (Time) adalah waktu yang diperlukan untuk menyelesaikan pekerjaan memotong singkong.

Hasil pada penelitian ini diolah

menggunakan komputer program SPSS.

\section{HASIL DAN PEMBAHASAN}

Data Karakteristik Subjek Penelitian

Deskripsi karakteristik subjek penelitian pada Tabel 1.

Tabel 5.1 Deskripsi Karakteristik Subjek Penelitian

\begin{tabular}{|c|c|c|c|c|}
\hline Variabel & $\mathrm{n}$ & Rerata & $\begin{array}{c}\text { Simpa } \\
\text { ng } \\
\text { Baku }\end{array}$ & $\begin{array}{c}\text { Rentang } \\
\text { an }\end{array}$ \\
\hline Umur (th) & 9 & 36,78 & 6,11 & $28-45$ \\
\hline $\begin{array}{l}\text { Tinggi } \\
\text { Badan } \\
(\mathrm{cm})\end{array}$ & 9 & $\begin{array}{c}150 \\
78\end{array}$ & 3,23 & $\begin{array}{c}145- \\
155\end{array}$ \\
\hline $\begin{array}{l}\text { Berat } \\
\text { Badan } \\
(\mathrm{kg})\end{array}$ & 9 & $\begin{array}{c}47,4 \\
4\end{array}$ & 5,003 & $40-55$ \\
\hline $\begin{array}{l}\text { Indeks } \\
\text { Massa } \\
\text { Tubuh }\end{array}$ & 9 & $\begin{array}{c}20,8 \\
7\end{array}$ & 2,10 & $\begin{array}{c}18,75- \\
22,91\end{array}$ \\
\hline $\begin{array}{l}\text { Pengalam } \\
\text { an Kerja } \\
\text { (th) }\end{array}$ & 9 & 3,33 & 1,50 & $1-5$ \\
\hline $\begin{array}{l}\text { Hasil } \\
\text { pemotong } \\
\text { rerata um } \\
\text { dengan rei } \\
\text { ditetapkan }\end{array}$ & $x_{0}$ & $\begin{array}{l}\text { sis terha } \\
\text { kong m } \\
\text { abjek } 36 \\
\text { yan umu } \\
\text { itu ant }\end{array}$ & $\begin{array}{l}\text { ap } 9 \text { or } \\
\text { nunjuk } \\
78 \pm \\
\text { subjek } \\
\text { a } 28\end{array}$ & $\begin{array}{l}\text { g pekerja } \\
\text { n bahwa } \\
1 \text { tahun, } \\
\text { ang telah } \\
5 \text { tahun. }\end{array}$ \\
\hline
\end{tabular}

Manuaba (1998) menyatakan kapasitas fisik seseorang mencapai puncaknya pada umur 25 tahun. Menurut Grandjean (2000), bahwa kondisi umur mempengaruhi kemampuan kerja fisik atau kekuatan otot seseorang, sedangkan kemampuan fisik maksimal seseorang dicapai pada umur antara 25-35 tahun, baik laki-laki maupun perempuan dan terus menurun seiring bertambahnya umur. Menurut Rodahl (1989) dan Pheasant (1991), kekuatan otot mulai menurun pada umur 39 tahun dan pada kisaran umur antara 50-60 tahun kekuatan otot hanya mencapai $75-85 \%$ dibandingkan orang yang berumur antara 25-35 tahun tersebut. Oleh karena itu, dapat disimpulkan bahwa rentangan umur subjek masih dalam kekuatan fisik otot optimal.

Berat badan subjek penelitian antara $40-55 \mathrm{~kg}$ dengan rerata $47,44 \pm 5,003 \mathrm{~kg}$, tinggi badan antara $145-155 \mathrm{~cm}$ dengan rerata $150,78 \pm 3,23 \mathrm{~cm}$, dan indeks massa tubuh berkisar antara 18,75-22,91 dengan rerata $20,87 \pm 2,10$. Indeks massa tubuh ideal untuk perempuan adalah 19-24. Sehingga subjek pemotong singkong tergolong berat badan ideal.

Meskipun indeks massa tubuh berpengaruh terhadap kebutuhan oksigen maksimal seseorang dan juga dapat meningkatkan terjadinya risiko keluhan muskuloskeletal, tetapi dalam penelitian ini semua subjek masih dalam rentangan berat badan ideal. Tingkat kebutuhan oksigen maupun terjadinya gangguan otot skeletal pada subjek yang diteliti, tidak disebabkan oleh indeks massa tubuh, tetapi dipengaruhi oleh beban kerja.

\section{Analisis Hasil Proses Kerja dan Sikap Kerja}

Analisis penambahan alas mesin dan pemberian peregangan dinamis sebagai berikut:

1. Sikap kerja pekerja pemotong singkong yang membungkuk dapat dihindarkan di ubah menjadi tegak. 
ISSN Print : 1411 - 951 X, ISSN Online : 20503-1716

\section{Jurnal Ergonomi Indonesia}

\section{(The Indonesian Journal of Ergonomic)}

Vol.3, No.1 : 1 Januari-Juni 2017

2. Pemberian peregangan dinamis dilakukan di sela jam kerja untuk memperbaiki fokus pekerja dan koreksi postur.

\section{Analisis Uji Normalitas Data}

Uji normalitas data menggunakan uji Shapiro-Wilk pada tingkat kemaknaan 0,05. Hasil uji Shapiro-Wilk tersebut disajikan pada Tabel 2

Tabel 2 Hasil Uji Normalitas Data dengan Uji Shapiro-Wilk ( $n=9)$

\begin{tabular}{|c|c|c|}
\hline Variabel & $\begin{array}{l}\text { Nilai } \\
\mathrm{p}\end{array}$ & Keterangan \\
\hline $\begin{array}{lr}\text { Denyut } & \text { Nadi } \\
\text { Istirahat } & \text { (Periode } \\
\text { I) } & \\
\end{array}$ & 0,113 & $\begin{array}{l}\text { Berdistribusi } \\
\text { normal }\end{array}$ \\
\hline $\begin{array}{lr}\text { Denyut } & \text { Nadi } \\
\text { Istirahat } & \text { (Periode } \\
\text { II) } & \\
\end{array}$ & 0,212 & $\begin{array}{l}\text { Berdistribusi } \\
\text { normal }\end{array}$ \\
\hline $\begin{array}{l}\text { Denyut Nadi } \\
\text { Kerja (Periode I) }\end{array}$ & 0,419 & $\begin{array}{l}\text { Berdistribusi } \\
\text { normal }\end{array}$ \\
\hline $\begin{array}{l}\text { Denyut Nadi } \\
\text { Kerja (Periode II) }\end{array}$ & 0,548 & $\begin{array}{l}\text { Berdistribusi } \\
\text { normal }\end{array}$ \\
\hline $\begin{array}{ll}\begin{array}{l}\text { Nadi } \\
\text { (Periode I) }\end{array} & \text { Kerja } \\
\end{array}$ & 0,179 & $\begin{array}{l}\text { Berdistribusi } \\
\text { normal }\end{array}$ \\
\hline $\begin{array}{ll}\text { Nadi } & \text { Kerja } \\
\text { (Periode II) } & \\
\end{array}$ & 0,127 & $\begin{array}{l}\text { Berdistribusi } \\
\text { normal }\end{array}$ \\
\hline $\begin{array}{l}\text { Keluhan } \\
\text { Muskuloskeletal } \\
\text { Sebelum Kerja } \\
\text { (Periode I) }\end{array}$ & 0,672 & $\begin{array}{l}\text { Berdistribusi } \\
\text { normal }\end{array}$ \\
\hline $\begin{array}{l}\text { Keluhan } \\
\text { Muskuloskeletal } \\
\text { Sebelum Kerja } \\
\text { (Periode II) }\end{array}$ & 0,425 & $\begin{array}{l}\text { Berdistribusi } \\
\text { normal }\end{array}$ \\
\hline $\begin{array}{l}\text { Keluhan } \\
\text { Muskuloskeletal } \\
\text { Sesudah Kerja } \\
\text { (Periode I) }\end{array}$ & 0,547 & $\begin{array}{l}\text { Berdistribusi } \\
\text { normal }\end{array}$ \\
\hline $\begin{array}{l}\text { Keluhan } \\
\text { Muskuloskeletal } \\
\text { Sesudah Kerja } \\
\text { (Periode II) }\end{array}$ & 0,452 & $\begin{array}{l}\text { Berdistribusi } \\
\text { normal }\end{array}$ \\
\hline $\begin{array}{l}\text { Produktivitas } \\
\text { Kerja } \\
\text { (Periode I) }\end{array}$ & 0,554 & $\begin{array}{l}\text { Berdistribusi } \\
\text { normal }\end{array}$ \\
\hline
\end{tabular}

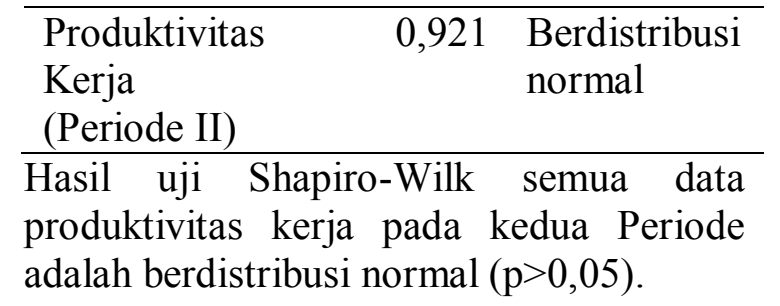

\section{Analisis Beban Kerja}

Beban kerja diukur berdasarkan denyut nadi pekerja melalui selisih denyut nadi kerja dengan denyut nadi istirahat.

Tabel 3 Hasil Uji Perbedaan Denyut Nadi Istirahat, Denyut Nadi Kerja dan Nadi Kerja Periode I dan Periode II $(n=9)$

\begin{tabular}{|c|c|c|c|c|}
\hline \multirow{2}{*}{ Variabel } & $\begin{array}{l}\text { Periode } \\
\text { I }\end{array}$ & $\begin{array}{c}\text { Periode } \\
\text { II }\end{array}$ & $\begin{array}{l}\text { Nilai } \\
\text { p }\end{array}$ & Keteran \\
\hline & $\begin{array}{l}\text { Rerata } \pm \\
\text { SB }\end{array}$ & $\begin{array}{l}\text { Rerata } \pm \\
\text { SB }\end{array}$ & & gan \\
\hline $\begin{array}{l}\text { Denyut } \\
\text { Nadi } \\
\text { Istirahat } \\
\text { (dpm) }\end{array}$ & $\begin{array}{l}68,40 \pm \\
0,11\end{array}$ & $\begin{array}{l}67,96 \pm \\
3,91\end{array}$ & 0,401 & $\begin{array}{l}\text { Tidak } \\
\text { Berbed } \\
\text { a } \\
\text { Bermak } \\
\text { na }\end{array}$ \\
\hline $\begin{array}{l}\text { Denyut } \\
\text { Nadi } \\
\text { Kerja } \\
\text { (dpm) }\end{array}$ & $\begin{array}{l}102,41 \\
\pm 0,41\end{array}$ & $\begin{array}{l}95,51 \pm \\
6,30\end{array}$ & 0,000 & $\begin{array}{l}\text { Berbed } \\
\text { a } \\
\text { Bermak } \\
\text { na }\end{array}$ \\
\hline $\begin{array}{l}\text { Nadi } \\
\text { Kerja } \\
(\mathrm{dpm})\end{array}$ & $\begin{array}{l}34,04 \pm \\
0,17\end{array}$ & $\begin{array}{l}27,54 \pm \\
6,58\end{array}$ & 0,000 & $\begin{array}{l}\text { Berbed } \\
\text { a } \\
\text { Bermak } \\
\text { na }\end{array}$ \\
\hline
\end{tabular}

Hasil uji t-paired, pada denyut nadi istirahat Periode I dan Periode II tidak berbeda bermakna. Rerata nadi kerja mengalami penurunan sekitar 15,35\% setelah dilakukan perlakuan dibandingkan tanpa dilakukan perlakuan.

Beban kerja dinilai dari peningkatan denyut nadi kerja. Denyut jantung/nadi per menit (dpm) dapat menggambarkan proses aktivitas dalam sel tubuh. Denyut jantung akan meningkat ketika tubuh dalam keadaan aktif, emosi dan ketakutan.

Denyut nadi istirahat (DNI) merupakan indikator kesesehatan manusia. Denyut nadi istirahat orang dewasa adalah 60-80 dpm yang diukur saat bangun pagi atau sebelum melakukan aktivitas apapun. Denyut nadi istirahat bisa lebih tinggi jika seseorang dalam keadaan ketakutan, habis 


\section{Jurnal Ergonomi Indonesia}

\section{(The Indonesian Journal of Ergonomic)}

berolahraga dan demam (Nursingbegin, 2011).

Menurut Kogi (1995) bahwa perbaikan alat kerja dengan perbaikan sikap kerja akan menurunkan beban kerja secara langsung berkonstribusi terhadap peningkatan produktivitas kerja. Dalam penelitian Sutajaya (1998) dilaporkan bahwa perbaikan kondisi kerja yang berimplikasi terhadap perbaikan sikap kerja pematung menurunkan beban kerja sebesar 24,86\%. Demikian juga penelitian yang dilakukan oleh Santosa (2013) pada perajin dodol di desa Penglatan Buleleng yang menyebutkan bahwa denyut nadi kerja pada kelompok kontrol didapatkan rerata sebesar $132,35 \pm 2,83 \mathrm{dpm}$, Sedangkan pada kelompok perlakuan didapatkan sebesar 109,71 \pm 4,45 dpm.

Penambahan alas mesin pada mesin pemotong singkong dapat menurunkan beban kerja. Hal tersebut menunjukkan bahwa secara fisiologis beban kardiovaskuler pada proses pemotongan pemotongan singkong menggunakan alas mesin lebih ringan dibandingkan tanpa alas mesin. Hal ini disebabkan karena selama proses pemotongan singkong tanpa alas mesin, pekerja terus mendapat beban akibat posisi tubuh yang membungkuk dengan pengerahan tetaga otot yang besar atau terjadi kontraksi otot statis. Pada pekerjaan dengan kontraksi otot statis diperlukan ATP atau energi yang lebih besar dari pada kontraksi otot dinamis. Di samping itu, kontraksi otot statis menyebabkan sirkulasi darah ke seluruh tubuh lebih banyak sehingga menyebabkan jantung bekerja lebih cepat. Dengan menggunakan alas mesin, beban kerja menjadi lebih ringan. Dengan demikian kontraksi otot yang bersifat statis dapat dihindarkan sehingga kebutuhan ATP atau energi lebih kecil (Grandjean, 1998).

\section{Analisis Keluhan Muskuloskeletal}

Vol.3, No.1 : 1 Januari-Juni 2017

Data keluhan musculoskeletal pekerja pemotong singkong berdistribusi normal, sehingga untuk menganalisis perbedaan efek perlakuan digunakan uji t-paired pada tingkat kepercayaan $\alpha=0,05$.

Tabel 4 Hasil Uji Perbedaan Skor Keluhan

Muskuloskeletal Sebelum dan Sesudah

Perlakuan pada Periode I dan Periode II

\begin{tabular}{|c|c|c|c|c|}
\hline & \multicolumn{3}{|c|}{$(n=9)$} & \\
\hline \multirow{3}{*}{ Variabel } & Periode & Periode & Nilai & \multirow{3}{*}{ Keterangan } \\
\hline & I & II & $\mathrm{P}$ & \\
\hline & $\begin{array}{l}\text { Rerata } \\
\pm \text { SB }\end{array}$ & $\begin{array}{l}\text { Rerata } \pm \\
\text { SB }\end{array}$ & & \\
\hline Keluhan & $29,67 \pm$ & $29,33 \pm$ & 0,195 & Tidak \\
\hline $\begin{array}{l}\text { Muskulo } \\
\text { skeletal } \\
\text { (Pre) }\end{array}$ & 0,67 & 1,80 & & $\begin{array}{l}\text { Berbeda } \\
\text { Bermakna }\end{array}$ \\
\hline Keluhan & $33,56 \pm$ & $31,56 \pm$ & 0,000 & Berbeda \\
\hline $\begin{array}{l}\text { Muskulo } \\
\text { skeletal } \\
\text { (Post) }\end{array}$ & 0,54 & 1,81 & & Bermakna \\
\hline
\end{tabular}

Uji beda data sesudah perlakuan antar kelompok mendapatkan hasil nilai p pada keluhan muskuloskeletal lebih kecil dari 0,05 sehingga Ho ditolak, yang berarti terdapat perbedaan signifikan pada keluhan muskuloskeletal pekerja pemotong singkong Periode I dibandingkan pada Periode II. Keluhan muskuloskeletal mengalami penurunan sekitar $13,15 \%$ setelah dilakukan perlakuan berupa penambahan alas mesin dan pemberian peregangan dinamis pada para pekerja pemotong singkong (Periode II). Dengan demikian perubahan stasiun kerja dan penyesuaian antropometri tubuh pekerja dapat menurunkan keluhan muskuloskeletal.

Dalam konsep ergonomi, yang menjadi prioritas utama adalah menyesuaikan desain dan sistem kerja mesin dengan kemampuan, kebolehan, dan keterbatasan manusia (fitting the job to the man) (Grandjean, 2000). Oleh karena itu, setiap interaksi manusia dengan mesin harus dirancang sedemikian rupa. Ardana (2012) juga membuktikan pengaplikasian prinsip-prinsip ergonomi dalam desain interior pembelajaran dapat memperbaiki sikap kerja sehingga mampu menurunkan keluhan otot rangka sebesar 50,98\%. 


\section{Jurnal Ergonomi Indonesia}

\section{(The Indonesian Journal of Ergonomic)}

Perbedaan besar penurunan keluhan muskuloskeletal tiap-tiap penelitian dipengaruhi oleh faktor-faktor seperti karakteristik subjek, jenis kegiatan yang diteliti, durasi kegiatan yang diteliti, pengaruh beban tambahan oleh lingkungan, serta beban psikologis yang timbul.

Keluhan muskuloskeletal yang dialami pekerja pemotong singkong sering terjadi pada bagian punggung dan pinggang. Hal ini disebabkan oleh sikap kerja membungkuk selama bekerja. Sikap kerja yang tidak alamiah atau sikap paksa menyebabkan terjadinya reaksi berupa keluhan pada sistem muskuloskeletal (Manuaba, 1992).

Sejalan dengan apa yang dinyatakan Ruccer \& Sunnel (2002) terhadap para dokter gigi, mereka menyatakan bahwa posisi praktek yang salah dalam bekerja terlebih lagi dalam menggunakan peralatan akan menyebabkan gangguan muskuloskeletal. Keadaan ini dapat ditanggulangi dengan melakukan perubahan sikap kerja yang tidak alamiah menjadi alamiah. Keluhan subjektif berupa gangguan otot skeletal dan kelelahan dapat diturunkan secara signifikan pada subjek dengan memperbaiki stasiun kerja dan sikap kerja yang lebih ergonomis (Chung \& Choi, 1997, Sutajaya dan Citrawathi, 2000).

\section{Analisis Produktivitas Kerja}

Luaran (output) adalah rerata jumlah singkong yang terpotong $(\mathrm{kg})$ per satuan waktu, sedangkan masukan (input) adalah beban yang diterima pekerja pemotong singkong berupa nadi kerja dan waktu (time) adalah waktu yang diperlukan untuk menyelesaikan pekerjaan memotong singkong. Produktivitas kerja adalah perbandingan antara luaran (output) dan masukan (input) per satuan waktu.

Tabel 5 Hasil Uji Perbedaan Produktivitas

Kerja Sebelum dan Sesudah Perlakuan

\begin{tabular}{cccc}
\multicolumn{4}{c}{$(\mathrm{n}=9)$} \\
\hline Variabel & Period Perio Nilai Keterangan
\end{tabular}

Vol.3, No.1 : 1 Januari-Juni 2017

\begin{tabular}{lllll}
\hline & e I & de II & $\mathrm{p}$ & \\
\cline { 2 - 3 } & Rerata & Rerat & & \\
& \pm SB & $\mathrm{a} \pm$ SB & & \\
\hline Produktivi & $1,64 \pm$ & $3,58 \pm$ & 0,000 & Berbeda \\
tas Kerja & 0,25 & 0,54 & & Bermakna \\
\hline \multicolumn{2}{c}{ Berdasarkan } & hasil & uji & t-paired
\end{tabular}

diketahui bahwa rerata produktivitas kerja antara periode I dan dengan periode II berbeda bermakna $(p<0,05)$, sehingga Ho ditolak, yang berarti produktivitas tanpa penambahan alas mesin dan pemberian peregangan dinamis tidak sama dibandingkan produktivitas dengan penambahan alas mesin dan pemberian peregangan dinamis. Disimpulkan bahwa produktivitas kerja meningkat sebesar $6,92 \%$ setelah dilakukan perlakuan berupa penambahan alas mesin dan pemberian peregangan dinamis pada pekerja pemotong singkong.

Pheasant (1991) menyatakan bahwa perbaikan sikap kerja dapat meningkatkan produktivitas sebesar 20 sampai dengan $25 \%$, sedangkan Dharmayanti melaporkan terjadi peningkatan produktivitas kerja sebesar $40,00 \%$ pada perajin bola mimpi, akibat adanya perbaikan alat kerja.

Analisis produktivitas tidak terlepas dari perhitungan break event point. Biaya yang harus dikeluarkan untuk penambahan alas mesin pemotong singkong yaitu pembuatan alas yang dibuat dari semen seharga Rp 500.000,-. Biaya-biaya lain yang timbul akibat pekerjaan pemotong singkong pada semua perlakuan adalah sama, maka dalam perhitungan break event point dapat diabaikan.

Selanjutnya manfaat atau keuntungan yang diperoleh rerata produksi pemotongan singkong sebelum penambahan alas kerja $9 \mathrm{~kg} / \mathrm{jam}$, dan setelah penambahan alas kerja $12 \mathrm{~kg} / \mathrm{jam}$, atau terjadi peningkatan produksi sebesar 3 $\mathrm{kg} / \mathrm{jam}$. Dengan penambahan alas mesin, ada peningkatan penghasilan sebesar Rp. 775.000,-/hari. Jadi break event point sudah tercapai setelah penambahan alas mesin pemotong singkong beroperasi selama 2 hari. 
Jurnal Ergonomi Indonesia

\section{(The Indonesian Journal of Ergonomic)}

\section{SIMPULAN DAN SARAN}

\section{Simpulan}

Berdasarkan analisis dan pembahasan, dapat disimpulkan sebagai berikut:

1. Penambahan alas mesin dan pemberian peregangan dinamis di bagian proses pemotongan singkong dapat menurunkan beban kerja sebesar 6,92\%.

2. Penambahan alas mesin dan pemberian peregangan dinamis di bagian proses pemotongan singkong dapat menurunkan keluhan muskuloskeletal sebesar $13,15 \%$.

3. Penambahan alas mesin dan pemberian peregangan dinamis di bagian proses pemotongan singkong dapat meningkatkan produktivitas kerja sebesar $15,35 \%$.

\section{Saran}

Berdasarkan hasil penelitian, hal-hal yang dapat disarankan adalah sebagai berikut.

1. Dalam upaya menurunkan beban kerja, keluhan muskuloskeletal, serta meningkatkan produktivitas kerja pada pekerja pemotong singkong maka disarankan untuk melakukan gerakan peregangan dinamis.

2. Peneliti dan pembaca dapat menginformasikan pada pekerja industri mengenai manfaat yang diperoleh dari penerapan cara ini.

3. Hasil dari penelitian ini bisa dipakai acuan bagi penelitian sejenis.

\section{DAFTAR PUSTAKA}

1. Anderson, B. 2010. Stretching in The Office. Serambi Ilmu Semesta. Jakarta.

2. Daryono,Y.,Sutjana, IDP., Muliarta, IM. 2016. Redesain Rakel dan Pemberian Peregangan Aktif Menurunkan Beban Kerja dan Keluhan Muskuloskeletal serta Meningkatkan Produktivitas Kerja Pekerja Sablon pada Industri Sablon Surya Bali di Denpasar. Jurnal
Vol.3, No.1 : 1 Januari-Juni 2017

Ergonomi Indonesia, Vol.2, No.2 : 1 Juli-Desember 2016. (cited 2017 April 16). Available from: unud.ac.id/index.php/jei/article/view/25 469.

3. Grandjean, E. 1998. Fitting the Task to the Man. A Text Book of Occupational Ergonomics, $4^{\text {th }}$ Edition, Taylor \& Francis Ltd, London.

4. Grandjean, E. Kroemer 2000. Fitting the Task To The Man. A Textbook of Occupational Of Ergonomics. 4 Th Ed. London : Taylor \& Francis.

5. International Labour Office (ILO) dan International Ergonomics Association(IEA). 2000. Petunjuk Praktis Ergonomik, Petunjuk yang Mudah Diterapkan dalam Meningkatkan Keselamatan dan Kondisi Kerja.Diterjemahkan oleh Tim Penerjemah DK3N. Jakarta.

6. Kogi, K. 1995. Paticipatory Ergonomics That Builds on Local Solution. Journal Human Ergol. Vol 24 (1). 27-135.

7. Manuaba, A. 1992a. Pengaruh Ergonomi Terhadap Produktivitas. Bunga Rampai Ergonomi Vol. 1. Program Studi Ergonomi - Fisiologi Kerja. Denpasar: Universitas Udayana.

8. Pheasant, S. 1991. Ergonomics, Work and Health. London: Macmillan Acsdemic Profesional Ltd.

9. Rodahl, K. 1989. The Physiology of Work. Philadelphia. Taylor \& Francis. London, New York.

10. Ruccer, L., Sunnel, S.2002. Ergonomic Risk Factors Associated with Clinical Dentistry. Journal of the California Dental Association. Vol.30, No.2. available from http://www.cda.org/member/pubs/journ al/jour0202/2002CDA Journal - Feature Article.htm. Accessed December 12, 2016.

11. Samson, M., Button, D.C., Chaouachi, A., Behm, D.G. 2012. Effect of dynamic and static stretching within general and activity specific warm-up 
ISSN Print : $1411-951 \mathrm{X}$, ISSN Online : 20503-1716

\section{Jurnal Ergonomi Indonesia}

\section{(The Indonesian Journal of Ergonomic)}

protocol. Journal of Sports Science and Medicine.

12. Sanders, M.S and Mc. Cormick, E.J. 1987. Human Factors in Engineering and Design. New York: Mc. Graw-Hill Book Company.

13. Santosa, I G. 2013, Perbaikan Kondisi dan Lingkungan Kerja dengan Intervensi Ergonomi Meningkatkan Kinerja dan Mutu Produk pada Perajin Dodol di Desa Penglatan, Buleleng (disertasi) Denpasar: Program Pascasarjana Universitas Udayana.

14. Suma'mur, PK. 1995. Higene Perusahaan dan Kesehatan Kerja. Jakarta: PT. Toko Gunung Agung.

15. Sutajaya, I.M. 1998. Perbaikan Kondisi Kerja Mengurangi Gangguan Terhadap Muskuloskeletal dan Denyut Nadi Kerja Serta Meningkatkan Produktivitas Pematung di Desa Pelihatan Ubud, Kabupaten Gianyar. Tesis Denpasar: Program Pascasarjana Universitas Udayana.

16. Sutajaya, I.M. \& Citrawathi, D.M. 2000. "Perbaikan Kondisi Kerja Mengurangi Beban Kerja dan Gangguan pada Sistem Muskuloskeletal Mahasiswa dalam menggunakan Mikroskop di Laboratorium Biologi STKIP Singaraja". Dalam Wignyo Soebroto, S. \& Wiratno, SE. Eds. Proceedings Seminar nasional Ergonomi. PT. Guna Widya. Surabaya. $239-242$. 